\title{
Infiltration and sediment production as affected by soil sur- face conditions in a shrubland of Patagonia, Argentina
}

\author{
CESAR M. ROSTAGNO
}

\section{Abstract}

Infiltration and sediment production of eroded and uneroded shrub interspace soils were evaluated in December 1986 in a severely grazed, arid range site in northeastern Patagonia. A rainfall simulator and small plots were used to collect the data. A desert pavement embedded in a vesicular crust characterized the surface soil of the eroded areas that occupy the lowest position in the microtopographic pattern. A granular, fine, and weak structured A horizon characterized the soil of uneroded areas. Slopes were similar for the eroded and uneroded areas. Surface soil bulk density, electrical conductivity, clay and organic matter content were significantly greater for the eroded than for the uneroded soils. Litter cover was significantly higher for the uneroded soils. Plant cover, although higher for the uneroded areas, was low $(<5 \%)$ for both eroded and uneroded areas.

Mean infiltration rate at the end of $35 \mathrm{~min}$, with the soil initially dry, was 0.8 and $6.1 \mathrm{~cm} / \mathrm{hr}$ for the eroded and uneroded soils, respectively. For the soil initially at field capacity, infiltration decreased to $0.6 \mathrm{~cm} / \mathrm{hr}$ and $4.1 \mathrm{~cm} / \mathrm{hr}$. Soil losses were higher from the eroded areas $(606 \mathrm{~kg} / \mathrm{ha}$ and $687 \mathrm{~kg} / \mathrm{ha})$ than for the uneroded areas $(291 \mathrm{~kg} / \mathrm{ha}$ and $556 \mathrm{~kg} / \mathrm{ha})$ when the solls were initially dry and at field capacity, respectively. Regression analysis indicated infiltration rate was positively related to litter cover and negatively related to gravel cover, whereas sediment production was negatively related to bulk density, plant, and gravel cover characteristics of the site.

Key Words: soll erosion, desert pavement, soil crust, Torriorthent, rangeland hydrology

Infiltration is the term applied to the process of water entry into the soil. The rate of this process, relative to the rate of water supply, determines how much water will enter the root zone, and how much, if any, will run off (Hillel 1982). Hence, the rate of infiltration affects not only the water budget of plant communities but also the amount of surface runoff and the attendant danger of erosion. Livestock grazing has the potential to alter soil surface hydrological properties (Blackburn et al. 1982). In shrub-dominated communities, shrub interspace areas are more sensitive to deterioration than canopy-covered areas (Beeskow et al. 1987). In arid and semiarid areas with sparse vegetation, the development of vesicular horizons tends to increase with the removal of herbaceous vegetation from shrub interspaces through overgrazing (Volk and Gyeger 1970). Vesicular horizons are usually accompanied by crust or desert pavement development (Evenari et al. 1974).

In various semiarid rangelands in Nevada the occurrence and morphology of vesicular horizons are negatively correlated with infiltration rate and positively correlated with sediment production (Blackburn 1975). As water moves more rapidly over a smooth, crusted surface with vesicular pores and lower infiltration, the potential for runoff and sediment production increases. This

\footnotetext{
Author is research scientist, Centro Nacional Patagónico, 28 de Julio 28, 9120 -Puerto Madryn, Chubut, Argentina. Research was funded by Consejo Nacional de Investigaciones Cientificas y Tecnicas (CONICET), República Argentina.

The author wishes to thank Dr. Ron Sosebee and Dr. Bill Dahl for suggestions for improving this manuscript, and Dario Puebla who helped with fieldwork.

Manuscript accepted 24 December 1988.
}

type of soil surface is often associated with early-seral range condition (Eckert et al. 1986). In the study site, crusted and paved areas produced by water removal of the surface soil and exposure of the subsoil occupy part of the shrub interspace areas, being more frequent in severely degraded sites. The objective of this study was to compare infiltration rate and sediment production of eroded and uneroded shrub interspace soils of an arid range site that had a history of overgrazing in northeastern Patagonia, and then to evaluate edaphic and vegetation variables as they influence these parameters. It is postulated that eroded soils present hyrological properties less favorable than uneroded ones, consequently, the aridity of the site will increase as the proportion of eroded areas increases.

\section{Study Area}

The study site is located in a closed basin of northeastern Patagonia, $15 \mathrm{~km}$ southwest of Puerto Madryn, Chubut $\left(42^{\circ} 46^{\prime} \mathrm{S}, 65^{\circ}\right.$ $00^{\prime} \mathrm{W}$ ). Average annual precipitation for the site is $170 \mathrm{~mm}$ and highly variable. The coefficient of variation for annual precipitation is $40 \%$ (Barros and Rivero 1982). Mean annual temperature is $13.5^{\circ} \mathrm{C}$.

Soils of the study site belong to the sandy, mixed, thermic family of typic Torriorthent derived from a $1-\mathrm{m}$ alluvium layer underlain by a compacted, cinereous substratum. The elevation is $75 \mathrm{~m}$ with a slope of $4 \%$. Vegetation of this range site is a shrubby steppe predominated by quilembai (Chuquiraga avellanedae Lorentz.). Additional shrubs are jarilla (Larrea divaricata Cav.), piquillin (Condalia microphylla Speg.), and yaoyin (Lycium chilense Miers ex Bertero). Grasses on this study site include pasto hilo (Poa lanuginosa Poiret ap Lamarck), Poa ligularis Nees ap Steudel, Stipa speciosa Trinius and Ruprecht, and Stipa neaei Nees ex Steudel.

Shrubs are distributed as discrete clumps or individuals which cover $29 \%$ of the surface. Shrub interspace areas comprise the remaining $71 \%$. In the shrub interspace areas, 2 types of soil surfaces are well differentiated:

i) The first, similar to that occurring beneath shrub clumps, is characterized by a granular, fine, weak structured $A$ horizon. This soil surface type occupies the higher positions in the microtopographic pattern and is referred to as the uneroded condition (Fig. 1 A).

ii) The second one is characterized by a well-developed desert pavement embedded in a vesicular crust (Fig. 1 B). This soilsurface type is referred to as the eroded surface condition and develops when the subsoil is exposed following removal of the topsoil by erosion. The position each surface type occupies in the microtopographic pattern is shown in Fig. 1 C.

The study area was intensively grazed in the past. However, for the past 5 years, all livestock have been excluded from the area.

\section{Methods}

A mobile, drip-type rainfall simulator similar to that described by Blackburn et al. (1974) was used to simulate rainfall on eight 

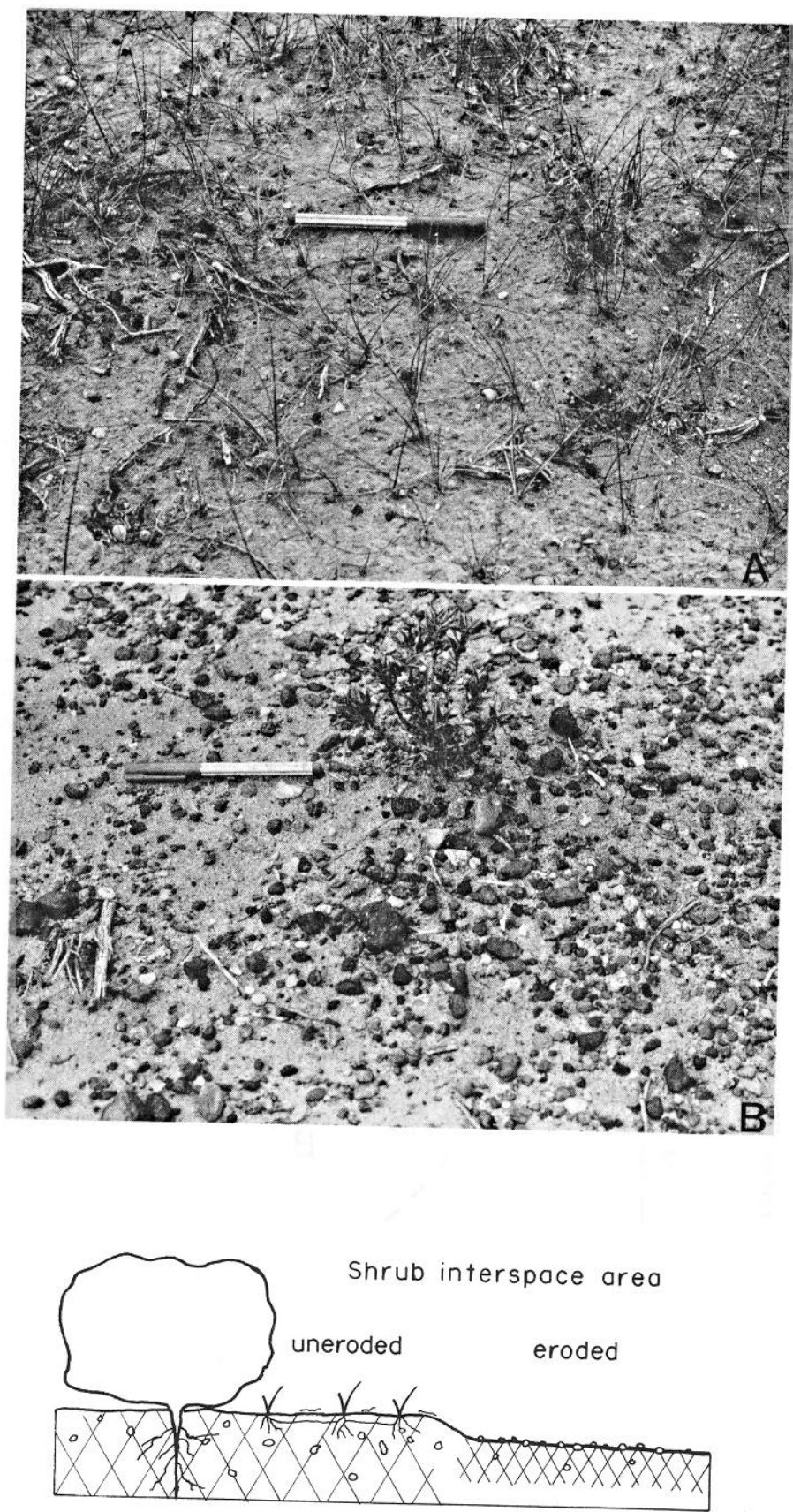

C

Fig. 1. Uneroded $(A)$ and eroded $(B)$ soil surface conditions that alternate in the shrub interspace area, and their positions in the microtopographic pattern (C).

$0.25-\mathrm{m}^{2}(62.5 \mathrm{~cm} \times 40 \mathrm{~cm})$ plots randomly located in each surface condition within a previously mapped quadrat of $30 \times 40 \mathrm{~m}$. Simulated rainfall was applied for $35 \mathrm{~min}$ to 2 antecedent moisture conditions: (1) soil surface horizon initially air dry and (2) soil surface horizon near field capacity ( $24 \mathrm{hr}$ after the dry run). Both conditions occur during the warm season when high intensity rainfall occurs. Rainfall application rate was $68 \mathrm{~mm} / \mathrm{hr}$. Data of Trelew station, $40 \mathrm{~km}$ south of the study area, indicate that a rainfall of this duration and intensity has a recurrence interval of 50 years (Vicenty et al. 1984). Drop diameter of the simulated rainfall was $2.5 \mathrm{~mm}$. Falling $2.1 \mathrm{~m}$, water drops of this size reach a velocity of $5.35 \mathrm{~m} / \mathrm{sec}$ or $72 \%$ of the terminal velocity of natural rainfall drops of this diameter (Epema and Riezebos 1983).

Runoff was collected at 5-min intervals during the 35-min simulated rainfall events. Infiltration was defined as the difference between total water applied during a given time period and total runoff during the same period. Initiation of runoff was defined as the time when measurable (i.e., approximately $20 \mathrm{cc}$ runoff in 30 seconds) runoff occurred from the plot (Devaurs and Gifford 1984). Sediment production was determined from the total runoff collected during each time interval by passing the sample through a Pt 325 sieve (45 um mesh). Sediment passing the sieve was determined for a sub-sample. This determination showed less variation than when taking an aliquot of the whole sediments. The 2 subfractions were dried at $105^{\circ} \mathrm{C}$ for $24 \mathrm{hr}$, weighed, converted to sediment yield $(\mathrm{kg} / \mathrm{ha})$ and used as an index of erosion.

Immediately before each simulated rainfall, a soil sample of the 0 to $5 \mathrm{~cm}$ depth was collected on areas adjacent to each plot for determination of organic carbon content by the Walkley-Black method (Allison 1965) and electrical conductivity of the saturation extract (U.S. Salinity Laboratory Staff 1954). Bulk density was determined by the excavation method (Blake 1965) and textural composition by the pipette method (Day 1965). Vegetation, litter, and gravel cover were visually estimated in each sample plot.

Significant differences between hydrological attributes on the two soil surface conditions were determined using Student's $t$-test. Variables associated with infiltration rate and sediment production were determined by means of forward stepwise multiple regression procedures using the Statistical Analysis System. Significant differences are at $P \leq 0.05$.

\section{Results and Discussion}

\section{Soils and Vegetation}

Selected soil and vegetation variables for the 2 soil surface conditions are given in Table 1. Eroded soils had higher density

Table 1. Mean soil and vegetation values for uneroded and eroded soil surface conditions $(\bar{x} \pm 1$ SD) in northeastern Patagonia, Argentina.

\begin{tabular}{lrrrr}
\hline \hline & \multicolumn{3}{c}{ Soil Surface Condition } \\
\cline { 2 - 5 } Variable & \multicolumn{3}{c}{ Uneroded } & \multicolumn{2}{c}{ Eroded } \\
\hline Bulk density $(\mathrm{g} / \mathrm{cc})$ & 1.34 & $(0.09)$ & 1.55 & $(0.15)$ \\
Sand (\%) & 77.14 & $(1.60)$ & 70.80 & $(3.90)$ \\
Clay (\%) & 6.50 & $(1.70)$ & 10.70 & $(2.60)$ \\
Organic matter (\%) & 1.19 & $(0.17)$ & 1.56 & $(0.28)$ \\
Electrical conductivity (mmhos/cm) & 0.22 & $(0.01)$ & 3.50 & $(4.30)$ \\
Gravel cover (\%) & 3.00 & $(2.10)$ & 60.00 & $(8.00)$ \\
Litter cover (\%) & 19.00 & $(12.10)$ & 4.50 & $(0.41)$ \\
Plant cover $(\%)$ & 4.50 & $(1.50)$ & 0.75 & $(1.29)$ \\
\hline
\end{tabular}

and electrical conductivity, and a finer texture than the uneroded soils. Percent organic matter was low in both eroded and uneroded soils, but highest on the eroded soils. This can be attributed to the higher clay content of eroded soils as more organic matter can be adsorbed on fine than on coarse-textured soils (Dregne 1976). Organic matter and clay content were positively related $(r=0.71)$. Gravel cover was substantially higher on eroded soils. Gravel concentration on the soil surface reflects the amount of topsoil eroded. On the eroded soils, gravels are embedded in the vesicular crust, but on the uneroded soils, gravel lies on the surface or is immersed in loose, fine materials.

Litter cover was higher and more viable on the uneroded soils. Vegetation cover was low for both soil surface conditions, although it was significantly higher on uneroded soils. On the study site, the dominant species associated with the uneroded soils was 
pasto hilo, a rhizomatous plant that grows on loose, sandy soils (Bertiller et al. 1981). This species is absent from the eroded soils.

\section{Infiltration Rate}

Under dry antecedent moisture conditions, mean infiltration rate was substantially greater $(P \leq 0.05)$ and less variable for the uneroded than for the eroded soils (Fig. 2A, Table 2). The mean

Table 2. Mean infiltration rates at the end of the $35 \mathrm{~min}$ simulated rainfall event and time to runoff under dry and field capacity antecedent moisture conditions for uneroded and eroded soll surface conditions ( $\bar{x} \pm$ 1SD) in northeastern Patagonia, Argentina.

\begin{tabular}{llllll}
\hline \hline $\begin{array}{l}\text { Soil Surface } \\
\text { Condition }\end{array}$ & \multicolumn{2}{c}{$\begin{array}{c}\text { Mean Infiltration Rate } \\
\mathrm{cm} / \mathrm{hr}\end{array}$} & & \multicolumn{2}{c}{$\begin{array}{c}\text { Time To Runoff } \\
\text { min }\end{array}$} \\
\cline { 2 - 4 } \cline { 5 - 6 } \cline { 5 - 6 } & Dry & Field capacity & Dry & Field capacity \\
\hline Uneroded & $6.1(0.67)$ & $4.1(1.31)$ & & $16.8(2.35)$ & $6.5(2.34)$ \\
Eroded & $0.8(0.47)$ & $0.6(0.08)$ & & $3.5(1.32)$ & $3.2(0.48)$ \\
\hline
\end{tabular}

infiltration rate under field capacity antecedent moisture conditions for the uneroded soils was significantly greater $(P \leq 0.05)$, and more variable than for the eroded soils (Fig. 2B).

Stepwise regression analysis was used to identify the variables associated with infiltration rate for both soil surface conditions combined. For the soils initially at field capacity the following equation was obtained:

Mean infiltration rate after $35 \mathrm{~min}=2.79+0.050$ (litter cover) -0.039 (gravel cover) $R=0.94$

Litter and gravel cover were the variables that most effectively predicted infiltration rate. Besides its direct effect on the infiltration process, litter cover integrates other variables related to it. Thus, litter cover was positively related to sand content $(r=0.68)$ and negatively related to bulk density $(r=0.57)$. Sand content was higher and bulk density was lower in the uneroded than in the eroded soils. In contrast, gravel cover, that was negatively related to infiltration rate $(r=0.94)$, was positively related to clay content $(r=0.82)$ and bulk density $(r=0.67)$. Desert pavement was closely related to the surface soil crust. The crust, considered to negatively affect infiltration rate (McIntyre 1958), was only present on the eroded areas. Thus, the gravel cover variable integrated the surface soil characteristics negatively related to infiltration rate. Blackburn (1975) found, on a big sagebrush community, that infiltration rate of dune interspace areas was 3-4 times lower than that of coppice dunes. Coppice dune and dune interspace areas exhibited soil surface horizon properties similar to the uneroded and eroded soils in this study respectively.

For the eroded soils differences between infiltration rate, for the 2 antecedent moisture conditions were not significantly different $(P \leq 0.05)$ (Table 2). However, for the uneroded soils, infiltration rate was significantly greater $(P \leq 0.05)$ for the soils initially dry than for the soils at field capacity.

Rainfall duration necessary to produce runoff was significantly greater $(P \leq 0.05)$ for uneroded than for eroded soils (Table 2$)$. Similar time-to-runoff was found for crusted and uncrusted soils of an open chenopod shrubland of southern Australia (Graetz and Tongway 1986) as well as in laboratory experiments (Cai et al. 1985, De Ploey and Bryan 1985), although slope and rainfall intensity were different.

\section{Runoff and Sediment Production}

Runoff and sediment production were significantly greater $(P \leq 0.05)$ from the eroded than from the uneroded soils for dry antecedent moisture condition only (Table 3 ). For the initially dry soil, sediment production from the eroded soils was twice that of uneroded soils. However, an 18-fold difference in total runoff

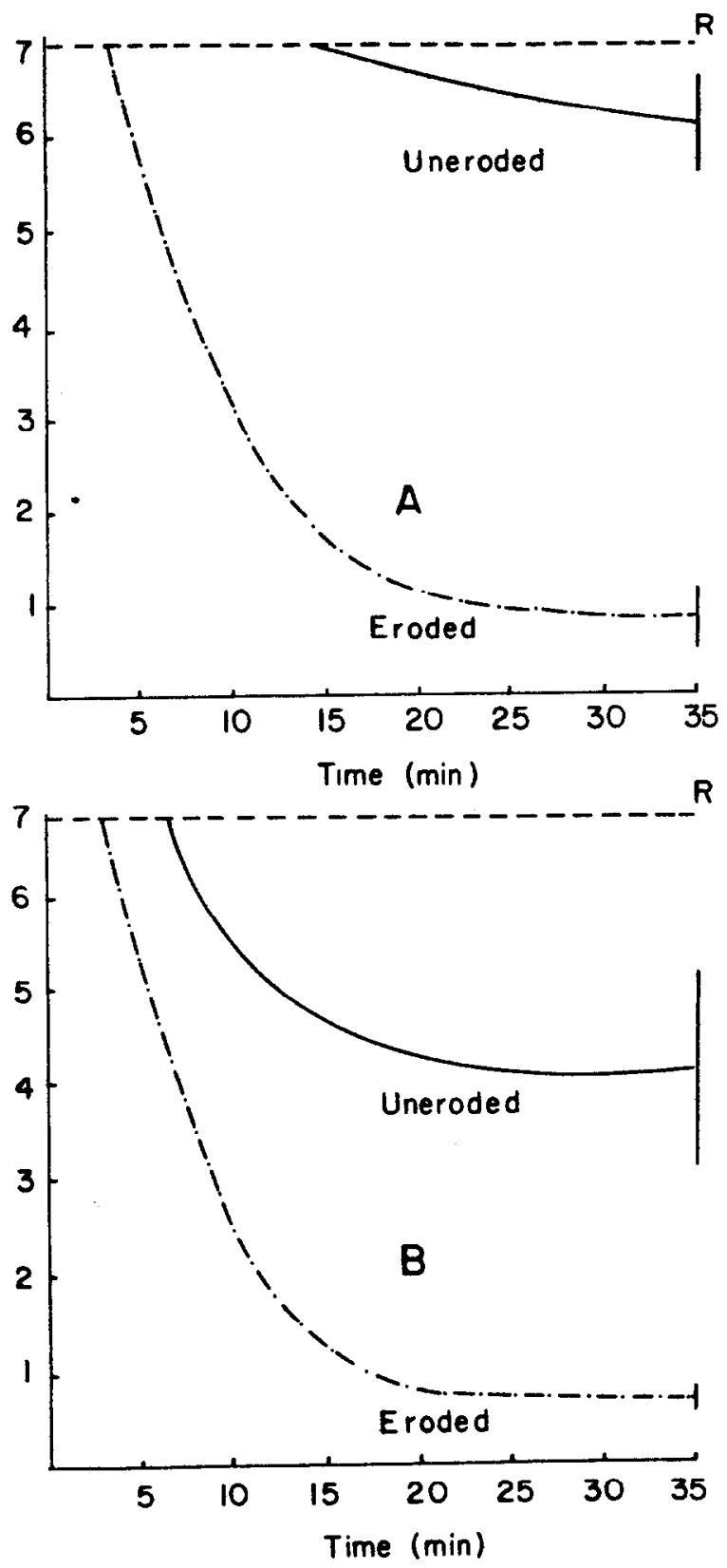

Fig. 2. Infiltration rates under dry $(A)$ and field capacity $(B)$ antecedent soil moisture for uneroded and eroded soil surface conditions. Vertical lines represent $95 \%$ confidence interval for mean infiltration rates after $35 \mathrm{~min} . R$ is applied rainfall intensity. Each curve is hand drawn using the mean values from 8 plots.

Table 3. Mean sediment production and runoff under dry and field capacity antecedent moisture conditions for uneroded and eroded soil surface conditions ( $\bar{x} \pm 1 S D)$ in northeastern Patagonia, Argentina.

\begin{tabular}{llllll}
\hline \hline $\begin{array}{l}\text { Soil Surface } \\
\text { Condition }\end{array}$ & \multicolumn{2}{c}{$\begin{array}{c}\text { Sediment Production } \\
(\mathrm{kg} / \text { ha) }\end{array}$} & & \multicolumn{2}{c}{$\begin{array}{c}\text { Runoff } \\
\text { (\% of applied rainfall) }\end{array}$} \\
\cline { 2 - 3 } & Dry & Field capacity & Dry & Field capacity \\
\hline Uneroded & $292(121)$ & $556(195)$ & & $4(3)$ & $32(12)$ \\
Eroded & $616(192)$ & $667(343)$ & $71(3)$ & $75(1)$ \\
\hline
\end{tabular}


existed between the 2 soil conditions, (i.e., $4 \%$ and $71 \%$ for the uneroded and eroded soils, respectively). Assuming that the rate of sediment production under similar slopes is a function of excess overland flow (Thornes 1985), the relatively small differences in sediment production compared to the great differences in runoff production may be accounted for by the protective effect of the cover of gravel on the eroded soils and the resistance of the crust.

Sediment production was significantly greater $(P \leq 0.05)$ from uneroded soils initially at field capacity than from uneroded soil initially dry (Table 3). Differences in sediment production and runoff from the eroded soils for the 2 antecedent moisture conditions were not significant $(P \geq 0.05)$.

When the combined data for the 2 surface conditions were used in the regression analysis, no variables met the 0.05 significance level for entry into the model. The stepwise multiple regression generated the following model for the uneroded soils with the soil initially at field capacity:

Mean sediment production after $35 \mathrm{~min}=2758-1486.4$ (bulk density) - 49.6 (plant cover) $R^{2}=0.95$

The model for the eroded soils with the soil initially at field capacity was:

Mean sediment production after $35 \mathrm{~min}=3625.5-1186$ (bulk density) - 20.1 (gravel cover) $R^{2}=0.65$

For the 2 soil conditions, bulk density was the strongest predictor of sediment production. Bulk density may influence sediment production by affecting soil detachment, with the soils more compacted being less detachable. Plant cover was the second strongest variable associated with sediment production for the uneroded soils. Although the influence of plant cover on sediment production is well understood (Thurow et al. 1986, Bedunah and Sosebee 1986), its effect on the study site is not clear since the low plant cover present on the uneroded areas may contribute little to soil loss control. For the eroded soils, gravel cover was the second most important variable predicting sediment production. Simanton et al. (1984) found that erosion ratios from macroplots with rock fragments decreased exponentially with the increase in percent rock cover. The influence of soil crusts on erosion is not well understood. Although, the resulting increased runoff due to low infiltration rates of the eroded soils enhanced erosive capacity (Bryan and De Ploey 1983), it is possible that this is more than offset by the increased erosion resistance of the crusted surface.

\section{Conclusions}

Topsoil erosion, the main degradation process affecting the soils of the study area, occurs in discrete patches in the shrub interspace areas. This process has generated 2 soil surface conditions that differ greatly in term of pedological as well as hydrological properties. The main difference between the 2 conditions with direct consequences on biological productivity was the reduced infiltration rate of the eroded soils. Results indicate that eroded soils provide less opportunity for soil water storage, producing most of the runoff generated from the site. This tends to accentuate the biological patchiness that characterizes more arid ecosystems, reducing also the ecosystem potential for production.

Differences in sediment production from the $\mathbf{2}$ soil surface conditions were not as high as expected considering the differences in runoff produced. The erosion process on the eroded soils seems to be reduced by soil compaction and the formation of a desert pavement that attenuates raindrop impact, thus reducing soil detachment.

\section{Literature Cited}

Allison, L.E. 1965. Organic carbon, p. 1367-1378. In: C.A. Black (ed). Methods of Soil Analysis. Monogr. Ser. Part 2, No. 9 Amer. Soc. Agron., Madison, Wis.

Barros, V., and M.M. Rjvero. 1982. Mapa de probabilidad de precipitacion de la Provincia del Chubut. Contribución No. 54. Centro Nacional Patagónico, Puerto Madryn, Chubut, Argentina.

Bedunah, DJ., and R.E. Sosebee. 1986. Influence of mesquite control on soil erosion on a depleted range site. J. Soil Water Conserv. 41:131-135.

Beeskow, A.M., H.F. Del Valle, and C.M. Rostagno. 1987. Los Sistemas fisiográficos de la región arida y semiarida de la provincia del Chubut, Argentina. SECYT Delegación Regional Patagonia, S.C. de Bariloche, Rio Negro, Argentina.

Bertiller, M.B., A.M. Beeskow, and M.P. Irisarr. 1981. Caracteres fisonómicos y floristicos de la vegetación del Chubut. 2. La Peninsula Valdes y el Istmo Ameghino. Contribución No. 41, Centro Nacional Patagónico, Puerto Madryn, Chubut, Argentina.

Blackburn, W.H. 1975. Factors influencing infiltration and sediment production of semiarid rangelands in Nevada. Water Resour. Res. 11:929-937.

Blackburn, W.H., R.O. Meeuwig, and C.M. Skau. 1974. A mobile infiltrometer for use on rangeland. J. Range Manage. 27:322-323.

Blackburn, W.H., R.W. Knight, and M.K. Wood. 1982. Impact of grazing on watersheds: A state of knowledge. Texas Agr. Exp. Sta. MP-1496.

Blake, B.R. 1965. Bulk density, p. 374-390. In: C.A. Black (ed). Methods of soil analysis. Monogr. Ser. Part 1, No. 9, Amer. Soc. Agron., Madison, Wis.

Bryan, R.B., and J. De Ploey. 1983. Comparability of soil erosion measurements with different laboratory rainfall simulators. Cantena Supplement 4:34-56.

Cai, Q.G., S.H. Luk, H. Chen, and Y.Z. Chen. 1985. Effect of surface crusting on water erosion: laboratory experiments on loess soils, China, p. 99-106. In: Proc. Symp. on Assessment of Soil Surface Sealing and Crusting. State University of Ghent. Ghent, Belgium.

Day, P.R. 1965. Particle fractionation and particle-size analysis, p. 545567. In: C.A. Black (ed). Methods of Soil Analysis. Monogr. Ser. Part 1, No. 9, Amer. Soc. Agron., Madison, Wis.

De Ploey, J., and R.B. Bryan. 1985. Time to runoff as a function of slope angle, p. 106-1 19. In: Proc. Symp. on Assessment of Soil Surface Sealing and Crusting. State University of Ghent, Belgium.

Devaurs, M., and G.F. Gifford. 1984. Variability of infiltration within large runoff plots on rangelands. J. Range Manage. 37:523-528.

Dregne, H.E. 1976. Soils of arid regions. Elsevier Sci. Pub. Co., New York.

Eckert, R.E., F.F. Peterson, and J.T. Belton. 1986. Relation between ecological range condition and proportion of soil-surface types. J. Range Manage. 39:409-413.

Epemn, G.F., and H.T. Riezebos. 1983. Fall velocity of water drops at different heights as a factor influencing erosivity of simulated rain. Catena Supplement 4:1-18.

Evenari, M., D.H. Yaalon, and Y. Gutterman. 1974. Note on the soils with vesicular structure in deserts. Z. Geomorphol. N.F. 18:162-172.

Graetz, R.D., and D.J. Tomgway. 1986. Influence of grazing management on vegetation, soil structure, and nutrient distribution and the infiltration of applied rainfall in a semiarid chenopod shrubland. Australian J. Ecol. 11:347-360.

Hillel, D. 1982. Introduction to soil physics. Academic Press. New York.

Melntyre, D.S. 1958. Permeability measurements of soil crusts formed by raindrop. Soil Sci. 85:185-189.

Simanton, J.R., E. Rawitz, and E.D. Shirley. 1984. Effects of rock fragments on erosion of semiarid rangelands soils, p. 65-72. In. J.D. Nichols, P.L. Brown, and W.J. Grant (eds). Erosion and productivity of soils containing rock fragments. Soil Sci. Soc. Amer. Spec. Pub. 13.

Thornes, J.B. 1985. The ecology of erosion. Geography 70:222-238.

Thurow, T.L., W.H. Blackburn, and C.A. Taylor, Jr. 1986. Hydrologic characteristics of vegetation types as affected by livestock grazing systems, Edwards Plateau, Texas. J. Range Manage. 39:505-508.

U.S.Salinity Laboratory Stafi. 1954. Diagnosis and improvement of saline and alkali soils. Agr. Handb. 80, USDA, U.S. Government Printing Office, Washington, D.C.

Vicenty, O.A., J.J. Serra, and A.D. Gabetta. 1984. Estudio de las precipitaciones en la ciudad de Trelew, Chubut. MESOP, RAWSON, Chubut, Argentina.

Volk, O.H., and E. Geyger. 1970. Schaumboden als Urache der Vegetationslosigkeit in arid Gebieten. Z. Geomorph. N.F. 14:79-95. 